\title{
Article \\ Effect of Genetically Diverse Pollen on Pollination, Pollen Tube Overgrow, Fruit Set and Morphology of Kiwiberry (Actinidia arguta)
}

\author{
Agnieszka Stasiak ${ }^{1}$, Piotr Latocha ${ }^{1, * \text { (D) and Monika Bieniasz }}{ }^{2}$ \\ 1 Department of Environmental Protection and Dendrology, Institute of Horticulture Sciences, \\ Warsaw University of Life Sciences-SGGW, Nowoursynowska 159, 02-787 Warsaw, Poland; \\ agnieszka_stasiak@sggw.edu.pl \\ 2 Department of Pomology and Apiculture, University of Agriculture in Cracow, 29 Listopada 54, \\ 31-425 Cracow, Poland; m.bieniasz@urk.edu.pl \\ * Correspondence: piotr_latocha@sggw.edu.pl
}

Citation: Stasiak, A.; Latocha, P.; Bieniasz, M. Effect of Genetically Diverse Pollen on Pollination, Pollen Tube Overgrow, Fruit Set and Morphology of Kiwiberry (Actinidia arguta). Agronomy 2021, 11, 1814. https://doi.org/10.3390/ agronomy11091814

Academic Editor: Francis Drummond

Received: 13 August 2021

Accepted: 7 September 2021

Published: 9 September 2021

Publisher's Note: MDPI stays neutral with regard to jurisdictional claims in published maps and institutional affiliations.

Copyright: (c) 2021 by the authors. Licensee MDPI, Basel, Switzerland. This article is an open access article distributed under the terms and conditions of the Creative Commons Attribution (CC BY) license (https:// creativecommons.org/licenses/by/ $4.0 /$ )

\begin{abstract}
Successful pollination and fertilization are crucial processes for obtaining a high yield, especially for dioecious plants such as A. arguta. Determination of pollen tube growth on stigma and fruit development parameters, which were investigated in this study, can enable the evaluation of male-female compatibility-one of the factors of successful pollination. Pollen quality and grain size were analysed for two years on six male cultivars of $A$. arguta and one of $A$. chinensis var. deliciosa. Results showed high pollen quality, both with parameters above $80 \%$. Pollen germination in vivo showed differences in pollen-stigma interactions. The highest positive interactions were observed for all female cultivar crosses with male 'Nostino' and 'Rubi' and the lowest one for A. chinensis var. deliciosa 'Tomuri'. However, fruit set and average fruit weight were equally high in most of the combinations (fruit set above $75 \%$ for the majority of combinations). Some differences were noticed in the average seed number per fruit and weight. All tested male cultivars were able to fertilize tested female cultivars, but taking into account other characteristics such as pollen efficiency, some male cultivars seemed to be more proper for commercial orchards. Using A. chinensis var. deliciosa pollen seems to be unreasonable in tested conditions.
\end{abstract}

Keywords: dioecy; pollen; stigma; tube growth; compatibility; fruit set; fruit quality

\section{Introduction}

Dioecy is not very common among fruit plants and applies to about $6 \%$ of all species [1] Actinidia genus, sea-buckthorn (Hippophaë rhamnoides L.), fig-tree (Ficus carica L.), or pistachio (Pistacia spp.) are examples of well-known dioecious fruit plants. Different theories have been presented in regards to possible ways for dioecy evolution and adaptation. Dioecy was seen as an evolutionary dead end. It is, however, possible that it could revert to hermaphroditism which accounts for its lower popularity in plant species [1]. The key problem in fruit production of dioecious species is that of proper pollination as it influences yield and fruit quality. The problem was thoroughly researched with respect to kiwifruit or fig $[2,3]$.

Kiwiberry, also called hardy kiwifruit or baby kiwi (Actinidia arguta (Siebold et Zucc.) Planch. ex Miq.), is a dioecious fruit woody wine and one of the most widespread species among the Actinidia genus, naturally occurring in Siberia, Korea, Japan, and China [4]. It can survive in frost of down to $-32{ }^{\circ} \mathrm{C}$ in midwinter [5] and may, therefore, be widely cultivated in areas with a temperate climate. Furthermore, kiwiberries have an edible, smooth, and hairless skin, and contain a high amount of biologically active ingredients with significant health-promoting properties and anticancer activity [5-7]. The chemical composition and good taste of the fruit make it highly attractive for consumers. Produc- 
tion of kiwiberry has increased in recent years worldwide and the fruit is regarded as a promising crop for the future $[6,8,9]$.

As kiwiberry is a dioecious plant, much attention is paid to its effective pollination. According to earlier research on A. chinensis var. deliciosa (kiwifruit), poor pollination due to the growing distance between male and female plants caused a reduction in the seed number and consequently, of the fruit mass [2,10]. It has not been clearly confirmed yet as to whether actinidia is wind-pollinated or insect-pollinated, yet according to recent studies insects are considered as the main pollen vector [10-12]. A common practice in kiwifruit plantations nowadays is artificial pollination using commercially available pollen. However, according to the latest research results, bee-pollinated plants produce $40 \%$ more fruits which also contain more seeds. They are also heavier and less variable [13]. No similar research results are available as kiwiberry is concerned, but preliminary experiments with supportive $A$. arguta pollination with $A$. chinensis pollen have already been made [14]. Tiyayon and Strik [15] observed a linear relationship between the number of seeds and fruit weight in $A$. arguta 'Ananasnaya'. Apart from the presence of a sufficient number of pollinating insects, the lower pollination in A. arguta, may be accounted for by pollen limitation as it turned out that male cultivars may differ substantially in the amount of pollen produced [12]. The stigma receptivity period seems to also be an important issue. It lasts in kiwifruit for about 4 days after anthesis, following which the stigma receptivity falls down and the fruit set is lower [16].

The source of pollen may affect the fruit set and yield. This was observed in a tissue culture-derived date palm (Phoenix dactylifera L.) cv. Barhee [17]. An impact of pollen source on fruit quality parameters, such as dry matter, phenolic content and biochemical seed composition in A. arguta or fruit set, fresh weight, seed weight, and colour, of flesh in seedlings of $A$. chinensis was also observed $[18,19]$. Several parameters, notably skin colour, fruit length or biochemical-total phenolics, flavonoids and anthocyanins, etc., were affected by the pollen source in dioecious fig fruit. However, basic parameters such as fruit diameter, weight or ripening time did not change in this species [20]. Pollen source may also influence the speed of pollen tube growth, as tested in vivo in olive (Olea europaea L.) [21]. Observations were also made on walnut (Juglans regia L.) and kiwifruit (A. deliciosa) indicating that tree age may influence pollen germination in vitro [22].

Shivanna et al. [23] argue that if pollen is compatible with the stigma, the pollen grains are able to germinate on the stigma. If pollination is not compatible, the pistil inhibits the pollen tube growth. However, pollination and fertilization may be influenced by many other factors, e.g., air temperature, as was discovered in the case of coconut (Cocos nucifera L.) [24], olive [21] and apples [25]. On the other hand, there are species, such as Galanthus nivalis, the male gametophytes of which are genetically adapted to develop in low temperatures [26].

The pollen source may impact yield size and fruit quality, by influencing the fertilization process, also in kiwiberries. However, to the best of our knowledge, no research results have been published to date on A. arguta fertilization. The aim of this study, therefore, was the investigation of male-female compatibility, based on determining pollen tube growth in vivo and the impact of genetically different pollen sources on basic fruit parameters in three female genotypes of $A$. arguta during two consecutive years.

\section{Materials and Methods}

\subsection{Experiment Location and Climate Conditions}

The experiment was conducted during two consecutive years (in 2015 and 2016) in a commercial orchard situated in the Masovian province in central Poland, (altitude $175 \mathrm{~m}$; latitude $51^{\circ} 47^{\prime} \mathrm{N}$; longitude $20^{\circ} 48^{\prime} \mathrm{E}$ ). The long-term annual temperature in that location averages about $8{ }^{\circ} \mathrm{C}$ and precipitation- $530 \mathrm{~mm}$. During the May-September period, the long-term average temperature was $18{ }^{\circ} \mathrm{C}$. Weather conditions (temperature and precipitation) during the flowering and intense fruit growth periods were monitored each year and compared after two years. 


\subsection{Plant Material and Phenology}

To evaluate pollen tube-pistil interaction, the three most popular cultivars in Poland, that is 'Geneva', 'Weiki' and 'Bingo' female A. arguta, were used. The flowering period started on the 5th of June with 'Bingo' and ended on the 20th of June with 'Weiki' in 2016 (Figure 1). In 2015, the flowering started two days later and ended on the same day as in 2015. Hand pollination was conducted on the 11th of June 2015 and on the 9th of June 2016 when at least $40 \%$ of the flowers opened. Pollen was collected from seven male cultivars. Four of these were A. arguta var. arguta ('Rubi', 'Nostino', 'Weiki Male' and 'Joker'), one was $A$. arguta var. purpurea ('Rot'), one hybrid genotype (A. arguta var. arguta $\times A$. arguta var. purpurea) -F7 and commercially available pollen of $A$. chinensis var. deliciosa 'Tomuri'. All male A. arguta cultivars were grown in the Experimental Garden of the Environmental Protection and Dendrology Department of the Warsaw University of Life Sciences (SGGW) in central Poland. Actinidia chinensis var. deliciosa pollen was imported from Argentine. All A. arguta cultivars were tetraploids, and A. chinensis var. deliciosa 'Tomuri' was a hexaploid.

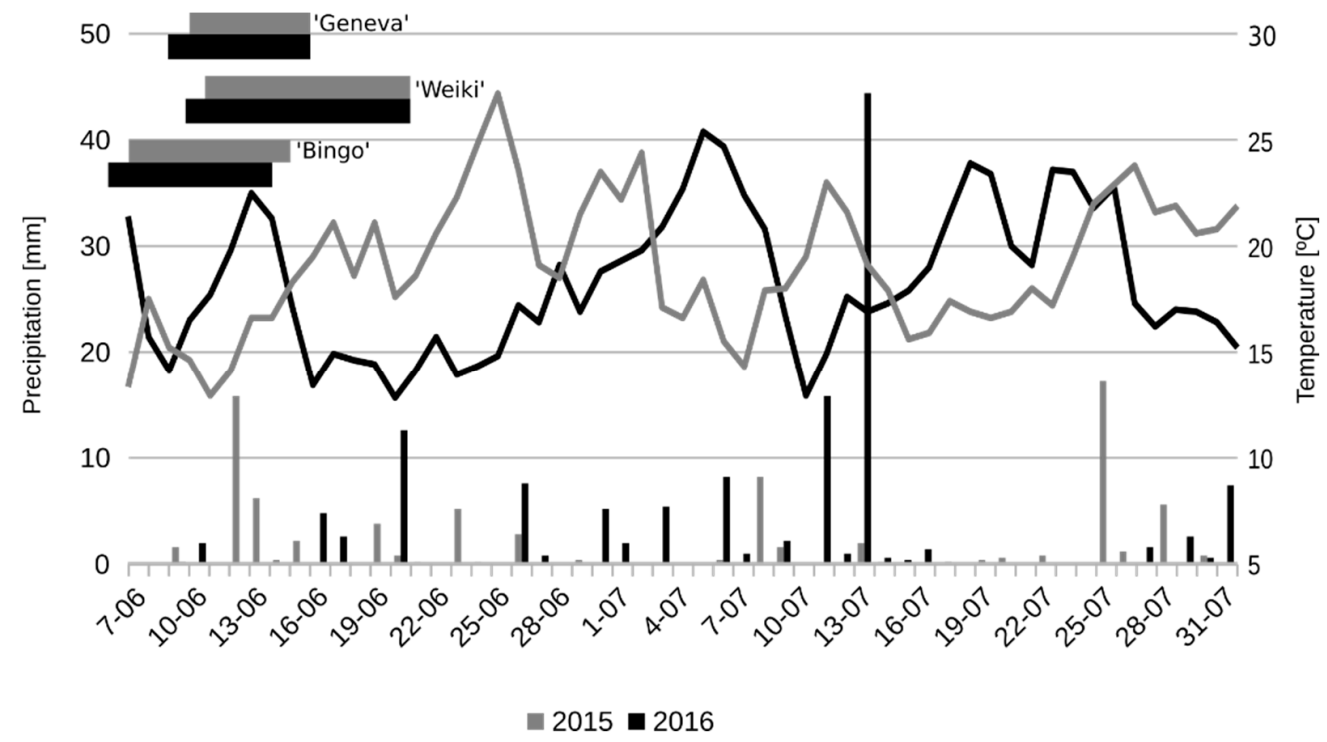

Figure 1. Temperature and precipitation during the flowering period and intense fruit growth in comparison to the flowering period of tested female $A$. arguta cultivars.

\subsection{Experimental Design}

Six-year-old female vines grown on a T-bar trellis support were maintained according to standard recommendations [27]. Each female cultivar was represented by four mature plants with similar vigour and abundance of flowers. On each plant, 28 shoots with at least 25 flowers were randomly chosen, marked and isolated with agro-textile bags on both plant sides one week before flowering started. For every female-male combination, four shoots (each on a separate plant) were marked. Controlled pollination was carried out during the full flowering phase of female plants. Each flower was treated once, using a small cosmetic brush covered with pollen grains. Isolators were removed seven days after petal fall (DAPF). Fruit buds were collected 10 DAPF from one shoot of each combination for pollen germination in vivo analysis. Three shoots were left for fruit growth.

The pollen from each male cultivar was collected just before anthesis. Fifty flowers at the balloon stage were collected for each male cultivar: stamens were cut and kept for $24 \mathrm{~h}$ in open Petri dishes under a heating lamp $\left(\sim \pm 25^{\circ} \mathrm{C}\right)$ to release pollen. It was then kept in the fridge $\left(4^{\circ} \mathrm{C}\right)$ until in vivo pollination was carried out and analysed afterwards in vitro. Imported and commercially produced 'Tomuri' pollen was stored at $-80^{\circ} \mathrm{C}$ after arrival until the start of the experiment. The 'Tomuri' pollen was gradually warmed up prior to the experiment. It was first kept at $-20{ }^{\circ} \mathrm{C}$ for several days, then in a refrigerator $\left(4^{\circ} \mathrm{C}\right)$ 
for one day and at room temperature on the day of the experiment. The 'Tomuri' pollen proceeded by the same procedure was used during both years.

\subsection{Pollen Quality and Size Measurements}

Pollen quality (viability and germability) in vitro was measured on the pollination day. The Alexander method was used for viability analysis. Viable pollen grains were stained in red and the non-viable ones in green [28]. Pollen germability was tested using a $15 \%$ sucrose agar medium poured into Petri dishes and allowed to cool to room temperature. Observations were taken using an AXIO Imager M2 microscope (from Carl Zeiss, Germany) after a $12 \mathrm{~h}$ incubation period at room temperature. The base for calculating both parameters consisted of 50 pollen grains, repeated four times at $100 \times$ magnification. A pollen grain was considered germinated only when the length of its pollen tube exceeded twice its grain diameter.

Pollen grain size was measured by using a light microscope and Axio Vs 40V 4.8.0.0 software. The probe of the 200 pollen grains was made up of a mixture obtained from many flowers of the same cultivar. Observations of pollen morphology were performed using a scanning electron microscope Phenom ProX (SEM). Part of the pollen grains population was vacuum dried and sputtered with chromium for imaging.

\subsection{Microscope Analysis of Growing Pollen Tubes}

The pollen germination on stigmas was analysed by a fluorescent microscope. At least ten fruit buds from one shoot per combination (all combination were taken from the same plant) were collected ten days after pollination and conserved in an FAA solution (ethanol $80 \%$, formalin, acetic acid 8:1:1) as described by Bieniasz et al. [29]. Briefly, the plant material was macerated for $12 \mathrm{~h}$ in $30 \% \mathrm{NaOH}$ for aniline blue staining of the preparations. Subsequently, after clearing the tissue with $6 \% \mathrm{H}_{2} \mathrm{O}_{2}$ and $\mathrm{H}_{2} \mathrm{O}$ rinsing, the pistils were stained with water-soluble aniline blue (dissolved in $0.1 \mathrm{~N}, \mathrm{~K}_{3} \mathrm{PO}_{4}$ ) for about $6 \mathrm{~h}$, followed by observations of pollen tube overgrowth through the pistil styles using a Zeiss Axio Imager M2 fluorescence microscope and ultraviolet light of a wavelength of about $356 \mathrm{~nm}$. Under these conditions, callose fluoresces bright yellow-green and contrasts strongly with the bluish or greyish fluorescence of the stylar tissue. The pollen tubes are outlined by a callose lining and irregularly spaced callose plugs [29]. The scale-developed for the assessment of pollen tube overgrowth by the neck of the pistil—is presented in Table 1.

Table 1. Pollen tube overgrowth assessment scale description.

\begin{tabular}{ccc}
\hline Points by Scale & Stigma & Style \\
\hline 3 & $\begin{array}{c}\text { Full coverage (more than 400 pollen } \\
\text { grains/stigma on average) } \\
\text { Medium coverage (above 100 to 400 } \\
\text { pollen grains / stigma on average) } \\
\text { Low coverage (below 100 pollen } \\
\text { grains/stigma on average) }\end{array}$ & $\begin{array}{c}\text { Maximum-above 90\% pollen } \\
\text { tube fulfilment of style } \\
\text { Medium-89-50\% }\end{array}$ \\
\hline
\end{tabular}

\subsection{Fruit Morphological Measurements}

Fruits were collected at their storage ripeness stage to check the most important morphological parameters, such as average single fruit weight, fruit set, average seed number per fruit and weight of 500 seeds.

The average single fruit weight per shoot was calculated based on all fruit of each shoot weight and the total number of fruits on the shoot. Fruit set was calculated as the ratio of all flowers per shoot to the number of fruits at harvest, the widely used and the most accurate method $[30,31]$. The result was presented as a percentage. Seed number was counted separately for each single fruit in 10 replications for each shoot. The weight of 500 seeds was measured for each shoot individually. 


\subsection{Statistical Analysis}

Pollen quality and grain size were analyzed with a one-way analysis of variance (ANOVA). Two-way ANOVA was applied to examine basic fruit parameters. In both cases, the normality of the model residuals was verified using the Shapiro-Wilk test. The data homoscedasticity was tested with Levene's test. No heteroscedasticity was detected. In the case when normality was violated, the logarithmic, Bliss or Box-Cox data transformation were applied. All analyses were carried out at a 5\% significance level. Homogenous groups were identified using a pairwise comparison, by performing the Tukey test.

The Spearman correlation coefficients were calculated for the examined fruit parameters and principal component analysis (PCA) was performed.

Statistical analyses were carried out using the Statistica StatSoft software version 13.0 (TIBCO Software Inc., 2017, http: / / statistica.io (accessed on 12 November 2020), Palo Alto, CA, USA) and the R program version 3.6.1 (R Core Team, 2016, http:/ /www.R-project.org/ (accessed on 2 September 2021).

\section{Results}

\subsection{Weather Conditions}

On the pollination day in 2015 , the average temperature stood at $17^{\circ} \mathrm{C}$. It increased to $22.5^{\circ} \mathrm{C}$ over the next two days, and decreased afterwards to $13-14{ }^{\circ} \mathrm{C}$ (Figure 1). In 2016, the temperature stood $15^{\circ} \mathrm{C}$ on the pollination day. It decreased to $13^{\circ} \mathrm{C}$ two days after pollination and then increased slowly up to $20^{\circ} \mathrm{C}$ during the next 6 days. Generally, the temperature during and a few days after pollination was higher in 2015 than in 2016. However, the average temperature during the flowering period and intense fruit growth was $0.8^{\circ} \mathrm{C}$ higher in 2016 than in $2015\left(19.1^{\circ} \mathrm{C}\right.$ and $18.3^{\circ} \mathrm{C}$, respectively).

Precipitation was almost two times higher in 2016 than in $2015(130.6 \mathrm{~mm}$ and $78.6 \mathrm{~mm}$, respectively). In 2015, precipitation was higher than $5 \mathrm{~mm}$ during six days, and above $10 \mathrm{~mm}$ during two. In 2016, precipitation exceeded $5 \mathrm{~mm}$ during seven days and $10 \mathrm{~mm}$ during three. On one of these days, precipitation was very high $(44.4 \mathrm{~mm})$ due to a heavy storm. Additionally, in 2016, precipitation during the first month of fruit growth was more evenly distributed than in 2015.

\subsection{Pollen Quality and Size}

The pollen viability and germability of $A$. arguta, as well as $A$. chinensis var. deliciosa, were very high during both seasons (Table 2). In 2015, the viability of all cultivars exceeded or equaled $94.0 \%$ of its value, and that of germability reached $89.0 \%$. The highest viability was noticed in the case of male 'Weiki' (100\%) and the lowest for 'Tomuri' $(94.0 \%)$. The germability was also the highest in the case of the male 'Weiki' (97.1\%), but the lowest for ' $\operatorname{Rot}^{\prime}(89.0 \%)$. In 2016, both parameters were also very high, exceeding $80.0 \%$. Lower results were observed for 'Rot, with viability of $82.5 \%$, and germability of $81.0 \%$. These results were significantly lower than those observed for the viability in 'Rubi' and F7, and for germability of male 'Weiki', 'Nostino' and F7.

Table 2. Pollen quality and grain size (data represent mean $\pm S D$ ).

\begin{tabular}{|c|c|c|c|c|c|}
\hline \multirow{2}{*}{ Genotype } & \multicolumn{2}{|c|}{ Viability [\%] } & \multicolumn{2}{|c|}{ Germability [\%] } & \multirow{2}{*}{$\begin{array}{l}\text { Pollen Grain } \\
\text { Size }[\mu \mathrm{m}] * *\end{array}$} \\
\hline & 2015 & 2016 & 2015 & 2016 & \\
\hline 'Weiki' & $100.0 \mathrm{a} * \pm 0.0$ & $98.4 \mathrm{ab} \pm 0.4$ & $97.1 \mathrm{a} \pm 1.2$ & $93.1 \mathrm{a}=$ & 26.4 \\
\hline ‘Joker' & $96.9 \mathrm{ab} \pm 0.9$ & $86.2 \mathrm{ab} \pm 0.5$ & $92.2 \mathrm{ab} \pm 0.3$ & $86.8 \mathrm{ab} \pm 4.0$ & $29.1 \mathrm{a} \pm 2.33$ \\
\hline 'Nostino' & $98.4 \mathrm{ab} \pm 1.4$ & $99.1 \mathrm{ab} \pm 0.7$ & $95.6 \mathrm{ab} \pm 1.2$ & $93.0 \mathrm{a} \pm 3.1$ & $28.2 \mathrm{a} \pm 1.91$ \\
\hline ‘Rot' & $96.6 \mathrm{ab} \pm 0.3$ & $82.5 b \pm 1.3$ & $89.0 b \pm 0.2$ & $81.0 b \pm 0.6$ & $27.4 \mathrm{a} \pm 2.57$ \\
\hline ‘Rubi' & $97.6 \mathrm{ab} \pm 0.4$ & $100.0 \mathrm{a} \pm 0.0$ & $92.1 \mathrm{ab} \pm 1.8$ & $91.0 \mathrm{ab} \pm 0.9$ & $25.8 \mathrm{a} \pm 1.88$ \\
\hline F7 & $99.8 \mathrm{ab} \pm 0.2$ & $100.0 \mathrm{a} \pm 0.0$ & $94.5 \mathrm{ab} \pm 3.8$ & $94.7 \mathrm{a} \pm 3.6$ & $25.4 \mathrm{a} \pm 2.02$ \\
\hline ‘Tomuri' & $94.0 \mathrm{~b} \pm 0.1$ & $89.3 \mathrm{ab} \pm 1.2$ & $90.8 \mathrm{ab} \pm 0.1$ & $86.4 \mathrm{a} \pm 1.3$ & $30.2 \mathrm{a} \pm 1.52$ \\
\hline
\end{tabular}

${ }^{*}$ Means for each column marked with different letters differ significantly according to Tukey HSD test at $p \leq 0.05$.

** Data from 2015. 
Pollen shape was oval with four furrows for both species (Figure 2B,C). The grain size varied between $25.4 \mu \mathrm{m}$ (genotype F7) and $30.2 \mu \mathrm{m}$ measured for A. chinensis var. deliciosa, but these differences were not statistically significant.
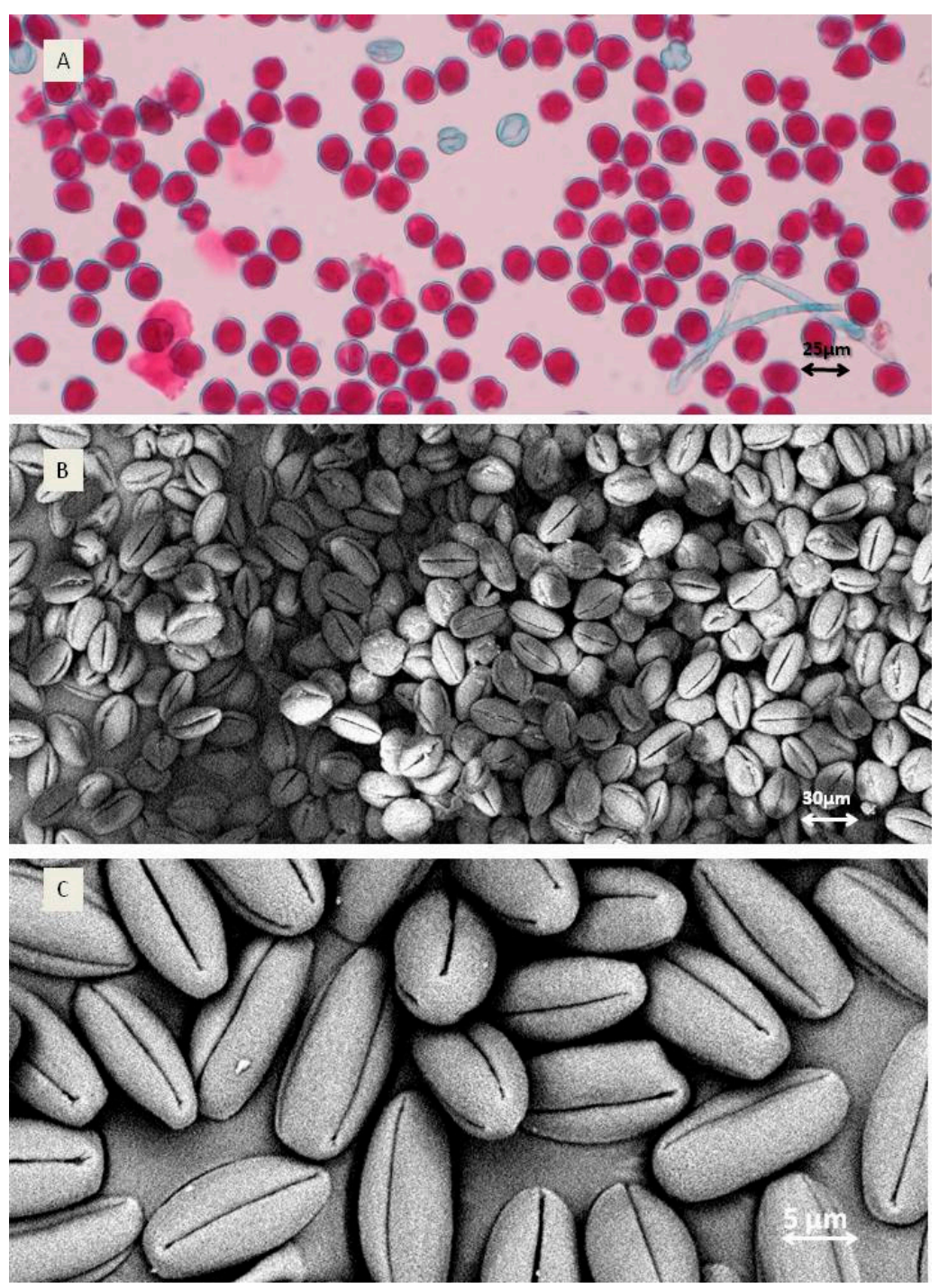

Figure 2. Pollen quality and shape. (A) Viability of A. arguta 'Weiki': red-viable and non-colourednon-viable pollen grains; (B) A. arguta 'Rubi' pollen grains; (C) shape of single A. arguta 'Rubi' pollen grain).

\subsection{Growing Pollen Tubes on Pistils}

Research on female-male pollen tube-pistil interaction was provided on three female cultivars commonly cultivated in Europe, and on seven male genotypes. As shown in Table 3, the differences between speed growth and amount of pollen tubes were clearly observed between certain combinations. 
Table 3. Comparison of female-male genotypes compatibility in 2015 and 2016.

\begin{tabular}{|c|c|c|c|c|c|c|c|c|c|}
\hline $\begin{array}{l}\text { Female } \\
\text { Cultivar }\end{array}$ & & 'Geneva' & & & 'Weiki' & & & 'Bingo' & \\
\hline $\begin{array}{l}\text { Pollen } \\
\text { Source } \\
\text { (Male } \\
\text { Cultivar) }\end{array}$ & $\begin{array}{l}\text { Pollen } \\
\text { Grains } \\
\text { on the } \\
\text { Stigma * }\end{array}$ & $\begin{array}{c}\text { Pollen } \\
\text { Tubes in } \\
\text { Half of } \\
\text { the Style } \\
* *\end{array}$ & $\begin{array}{c}\text { Pollen } \\
\text { Tubes in } \\
\text { Base of } \\
\text { the Style } \\
* * *\end{array}$ & $\begin{array}{c}\text { Pollen } \\
\text { Grains } \\
\text { on the } \\
\text { Stigma * }\end{array}$ & $\begin{array}{c}\text { Pollen } \\
\text { Tubes in } \\
\text { Half of } \\
\text { the Style } \\
* *\end{array}$ & $\begin{array}{c}\text { Pollen } \\
\text { Tubes in } \\
\text { Base of } \\
\text { the Style } \\
* * *\end{array}$ & $\begin{array}{l}\text { Pollen } \\
\text { Grains } \\
\text { on the } \\
\text { Stigma * }\end{array}$ & $\begin{array}{c}\text { Pollen } \\
\text { Tubes in } \\
\text { Half of } \\
\text { the Style } \\
* *\end{array}$ & $\begin{array}{c}\text { Pollen } \\
\text { Tubes in } \\
\text { Base of } \\
\text { the Style } \\
* * *\end{array}$ \\
\hline \multicolumn{10}{|c|}{2015} \\
\hline 'Weiki' & 3 & 3 & 3 & 3 & 3 & 3 & 2 & 2 & 2 \\
\hline 'Joker' & 3 & 3 & 3 & 2 & 2 & 2 & 2 & 2 & 1 \\
\hline 'Nostino' & 3 & 3 & 2 & 3 & 3 & 3 & 3 & 2 & 2 \\
\hline${ }^{\prime} \operatorname{Rot}^{\prime}$ & 2 & 1 & 1 & 1 & 1 & 1 & 2 & 1 & 1 \\
\hline ‘Rubi' & 3 & 3 & 3 & 3 & 3 & 3 & 3 & 3 & 3 \\
\hline F7 & 1 & 1 & 1 & 3 & 2 & 2 & 2 & 1 & 1 \\
\hline 'Tomuri' & 1 & 1 & 1 & 2 & 2 & 2 & 2 & 2 & 1 \\
\hline \multicolumn{10}{|c|}{2016} \\
\hline ‘Weiki' & 2 & 2 & 2 & 2 & 2 & 2 & 2 & 2 & 2 \\
\hline 'Joker' & 2 & 2 & 2 & 2 & 2 & 2 & 2 & 2 & 2 \\
\hline 'Nostino' & 2 & 2 & 2 & 3 & 3 & 3 & 3 & 3 & 3 \\
\hline 'Rot' & 3 & 2 & 2 & 2 & 2 & 2 & 3 & 2 & 2 \\
\hline ‘Rubi' & 2 & 2 & 2 & 3 & 3 & 3 & 3 & 3 & 3 \\
\hline F7 & 2 & 2 & 2 & 2 & 2 & 2 & 3 & 2 & 2 \\
\hline 'Tomuri' & 2 & 2 & 2 & 2 & 2 & 2 & 2 & 2 & 2 \\
\hline
\end{tabular}

* Where 3 means stigma was fully covered by pollen, which was more than 400 pollen grains in average; 2-average covering stigma with above 100 and below 400 of pollen grains; 1 -below 100 pollen grains on stigma; ** Where 3 means above $90 \%$ of style was filled with pollen tubes; 2 - 50-89\%; 1 - below $50 \%$; *** Like ** in the style base.

Microscope analysis showed that in 2015 the highest pollination rate and the amount of pollen tubes in the style were observed when 'Geneva' was pollinated with male 'Weiki', 'Joker', 'Nostino' and 'Rubi' pollen (Table 3)—rate 3, according to Table 1 (see Materials and Methods section). Male 'Weiki', 'Nostino', 'Rubi' and 'F7' were used to pollinate the female 'Weiki' and Rubi' for 'Bingo'. The highest number of pollen tubes was observed in the style base when 'Geneva' was pollinated with male 'Weiki', 'Joker' and 'Rubi' pollen, female 'Weiki' with male Weiki', 'Nostino' and 'Rubi', and only with 'Rubi' for female 'Bingo'. The lowest effectiveness of pollen tube growth with respect to the style base level was observed in the case of 'Geneva' when pollinated with 'Tomuri' and F7, in the case of 'Weiki' - when pollinated with 'Rot', and in the case of 'Bingo' when pollinated with 'Joker', 'Rot', F7 and 'Tomuri'.

In 2016, pollination and pollen tube growth were similar for all combinations, however, the highest pollination rate was noticed for combinations of 'Geneva' $\times$ 'Rot', 'Weiki' $\times$ 'Nostino' and 'Weiki' $\times$ 'Rubi' and 'Bingo' pollinated with 'Nostino', 'Rot', 'Rubi' and F7 (Table 3, Figure 3).

This shows that some similar observations were made during each year such as with respect to the high pollination rate for crosses of 'Weiki' with 'Nostino' and 'Rubi', as well as 'Bingo' with 'Rubi'. However, a seasonal impact was also observed for other combinations, with a high level of stigma covering with pollen or pollen tube growth through style noticed only in one year.

Summarising the above, 'Rubi' and 'Nostino' pollen showed the highest positive interaction with the style of all-female cultivars in both years, while 'Tomuri' 'Rot' and F7 indicated the lowest, at least during the first season. 

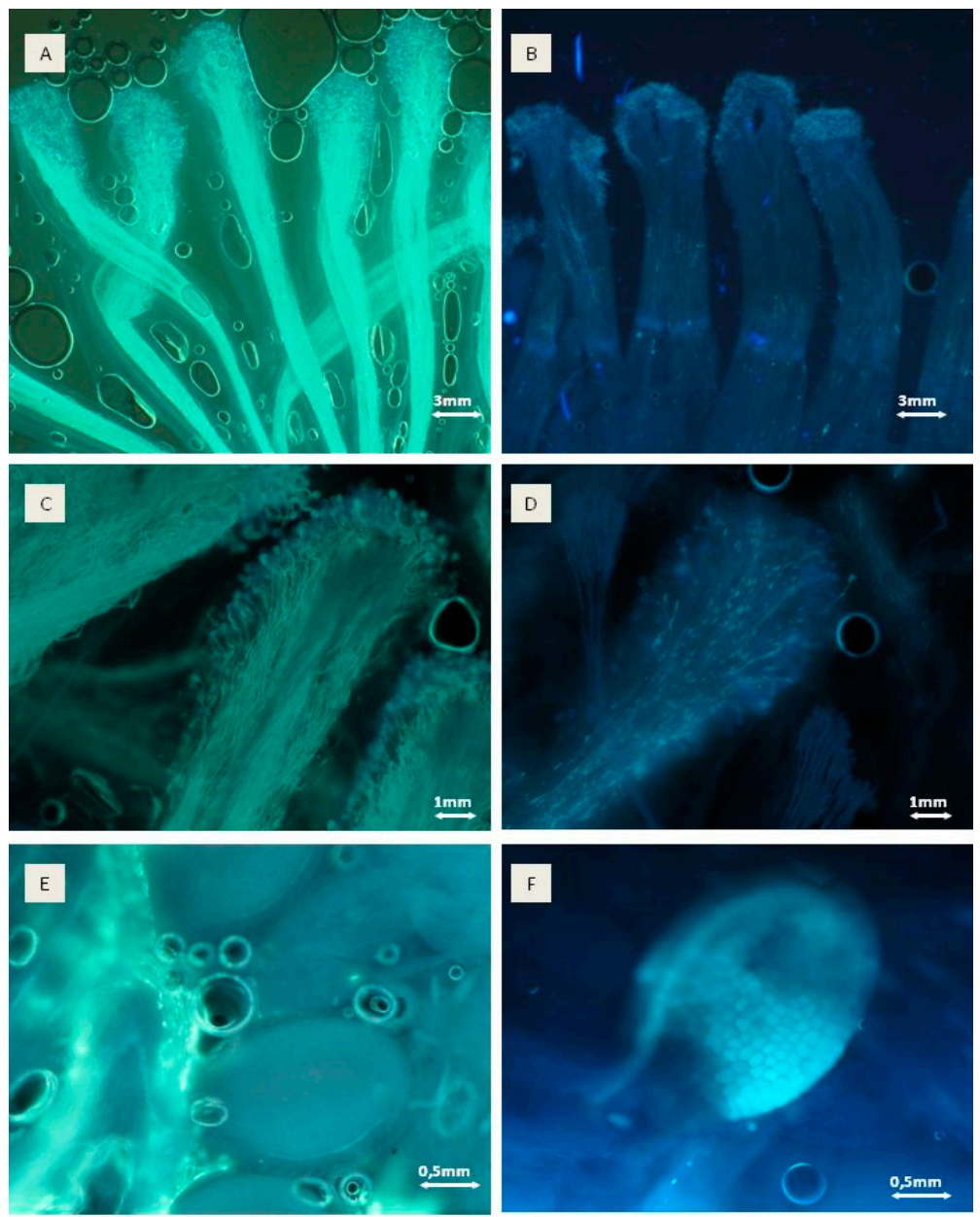

Figure 3. Pollen tube growth. (A,C,E) - pollen tube growth rated 3 according to Table $1 ;(\mathbf{B}, \mathbf{D}, \mathbf{F})$ pollen tube growth rated 1 according to Table 1. (A,B)-growing through the style; (C,D)-pollen grains germinating on stigma; (E) - pollen tubes near ovules; (F)—non fertilized.

\subsection{Influence of Genetically Diverse Pollen on the Fruit Morphology}

The basic pollination efficacy indicators we used in the study, covering the percentage of fruit set, average fruit weight, average number of seeds per fruit, and the weight of 500 seeds. Statistical analysis of the fruit set showed the impact of pollinizer only in 'Geneva' when pollination with 'Rot' pollen indicated a higher average fruit set (96.1\%) than for 'Joker' (77.9\%) (Table 4). A significantly higher average fruit set in 2016 than 2015 was observed.

Similarly, the impact of the genetically diverse pollen on average fruit weight was observed only for 'Geneva'. The heaviest fruit was found for combinations with the 'Nostino' pollen (7.69 g) than 'Tomuri' and 'Weiki' (5.97 g and $6.04 \mathrm{~g}$, respectively). For other female cultivars, genetically diverse pollen had no impact on the average fruit set but some differences between both seasons were observed. The average 'Geneva' and 'Weiki' fruit was heavier in 2016 while 'Bingo' in 2015. 
Table 4. Basic fruit parameters gained in different pollination combinations (data represent mean \pm SD).

\begin{tabular}{|c|c|c|c|c|c|c|}
\hline \multirow{2}{*}{$\begin{array}{c}\begin{array}{c}\text { Female } \\
\text { Cultivar }\end{array} \\
\text { Male Cultivar }\end{array}$} & \multicolumn{2}{|c|}{ 'Geneva' } & \multicolumn{2}{|c|}{ 'Weiki' } & \multicolumn{2}{|c|}{ 'Bingo' } \\
\hline & Fruit Set [\%] & $\begin{array}{c}\text { Average Fruit } \\
\text { Weight [g] }\end{array}$ & Fruit Set $[\%]$ & $\begin{array}{c}\text { Average Fruit } \\
\text { Weight [g] }\end{array}$ & Fruit Set $[\%]$ & $\begin{array}{c}\text { Average Fruit } \\
\text { Weight [g] }\end{array}$ \\
\hline \multicolumn{7}{|c|}{ Male cultivar } \\
\hline \multicolumn{2}{|c|}{ Transformation Bliss } & \multicolumn{3}{|c|}{ Bliss } & $\log _{10}$ & Box-Cox \\
\hline F7 & $83.9 \mathrm{ab} \pm 7.9$ & $5.92 b \pm 1.18$ & $89.1 \mathrm{a} \pm 6.7$ & $6.14 \mathrm{a} \pm 1.71$ & $75.8 \mathrm{a} \pm 17.7$ & $6.39 \mathrm{a} \pm 1.58$ \\
\hline 'Joker' & $77.9 \mathrm{~b} \pm 10.0$ & $6.51 \mathrm{ab} \pm 0.89$ & $82.6 \mathrm{a} \pm 9.3$ & $6.08 \mathrm{a} \pm 1.51$ & $80.4 \mathrm{a} \pm 15.1$ & $6.87 \mathrm{a} \pm 0.66$ \\
\hline 'Nostino' & $89.8 \mathrm{ab} \pm 6.3$ & $7.69 \mathrm{a} \pm 1.04$ & $92.0 \mathrm{a} \pm 6.6$ & $7.37 \mathrm{a} \pm 2.04$ & $85.0 \mathrm{a} \pm 15.6$ & $7.29 \mathrm{a} \pm 1.91$ \\
\hline 'Rot' & $96.1 \mathrm{a} \pm 6.5$ & $6.86 \mathrm{ab} \pm 1.46$ & $93.9 \mathrm{a} \pm 8.0$ & $6.98 \mathrm{a} \pm 2.09$ & $89.6 \mathrm{a} \pm 7.0$ & $7.74 \mathrm{a} \pm 2.54$ \\
\hline 'Rubi' & $90.4 \mathrm{ab} \pm 8.8$ & $7.28 \mathrm{ab} \pm 1.27$ & $85.0 \mathrm{a} \pm 14.8$ & $8.45 \mathrm{a} \pm 2.30$ & $84.1 \mathrm{a} \pm 9.2$ & $7.42 \mathrm{a} \pm 1.91$ \\
\hline 'Tomuri' & $92.4 \mathrm{ab} \pm 6.5$ & $5.97 \mathrm{~b} \pm 1.02$ & $88.8 \mathrm{a} \pm 6.7$ & $6.45 \mathrm{a} \pm 1.04$ & $68.9 \mathrm{a} \pm 20.1$ & $6.99 \mathrm{a} \pm 2.45$ \\
\hline ‘Weiki' & $87.5 \mathrm{ab} \pm 7.8$ & $6.04 \mathrm{~b} \pm 0.71$ & $96.7 \mathrm{a} \pm 8.2$ & $6.44 \mathrm{a} \pm 1.41$ & $85.6 \mathrm{a} \pm 13.2$ & $7.34 \mathrm{a} \pm 0.81$ \\
\hline \multicolumn{7}{|c|}{ Year } \\
\hline 2015 & $86.9 b \pm 9.7$ & $6.00 \mathrm{~b} \pm 0.78$ & $90.7 \mathrm{a} \pm 8.5$ & $5.77 \mathrm{~b} \pm 1.56$ & $81.5 \mathrm{a} \pm 13.9$ & $8.33 \mathrm{a} \pm 1.61$ \\
\hline 2016 & $89.7 \mathrm{a} \pm 8.4$ & $7.07 \mathrm{a} \pm 1.30$ & $88.7 \mathrm{~b} \pm 10.6$ & $7.70 \mathrm{a} \pm 1.59$ & $81.1 \mathrm{a} \pm 16.4$ & $6.16 \mathrm{~b} \pm 1.15$ \\
\hline
\end{tabular}

Data were analysed using a two-way ANOVA and Tukey's HSD test, with a significance level of $p \leq 0.05$. Values in each column marked with the different letter differ significantly.

The two-year average seed number ranged between 110.0 and 185.1 items per fruit (Table 5). Generally, fruit contained on average a higher number of seeds in 2015 than in 2016. 'Geneva' fruit had a lower number of seeds than 'Weiki' or 'Bingo'. Depending on the pollinizer, similar differences in average seed number for all tested female cultivars were noted. The higher number of seeds per 'Geneva' fruit was recorded when pollen of male 'Rot', 'Nostino', 'Rubi' and F7 (133.9-139.5 items on average) were used. In contrast, the lowest number was found following pollination with the 'Joker' or 'Tomuri' pollen (110.0-111.9 items on average). Similarly, a higher seed number per fruit for 'Weiki' was found when 'Rubi' pollen was used (173.9 items on average) than in fruit where 'Joker' pollen was used (142.3 items on average). The results observed for 'Bingo' showed that the average number of seeds per fruit was higher when 'Rot' and 'Rubi' pollen were used (118.1-135.1 items) than in fruit where flowers were pollinated by 'Joker' pollen (154.8 items on average). It should be noted that in 2016, part of the seeds in the all-female $\times$ A. chinensis var. deliciosa 'Tomuri' combinations were probably underdeveloped (were flat and probably lacking the embryo).

The average 500 seed weight was higher in 2016 than in 2015 for all combinations of female cultivars. An impact of the pollen source was observed for every female cultivar. The general trend we observed was that of the highest seed average weight for female $\times$ 'Nostino' (0.73-0.88 g) combinations and the lowest for the A. chinensis var. deliciosa 'Tomuri' (0.26-0.65 g) crossing. When analysing female cultivars separately, starting from 'Geneva', a higher seed weight was also noticed for crosses with 'Rubi', 'Weiki' and 'Joker'. Fruit of female 'Weiki' and 'Weiki 'male or 'Rubi' crosses produced heavier seeds than crosses with 'Tomuri' (0.77-0.80 g and $0.57 \mathrm{~g}$, respectively). The two-years results obtained for 'Bingo' confirmed observations made for other female cultivars to the effect that the significantly lowest seed weight was recorded when 'Tomuri' served as the pollen donor. This difference was the greatest for this combination and reached about $64 \%$ (Table 5). A higher seed weight for this cultivar was noted when 'Nostino', 'Weiki' and 'Joker' pollen was used.

As mentioned before, a large amount of not fully developed seeds was observed, especially in the combination of 'Bingo' with the 'Tomuri' pollen, resulting in a lower average seed weight. 
Table 5. Basic seeds parameters gained in different pollination combinations (data represent mean \pm SD).

\begin{tabular}{|c|c|c|c|c|c|c|}
\hline $\begin{array}{l}\text { Female } \\
\text { Cultivar }\end{array}$ & \multicolumn{2}{|c|}{ 'Geneva' } & \multicolumn{2}{|c|}{ 'Weiki' } & \multicolumn{2}{|c|}{ 'Bingo' } \\
\hline Male Cultivar & $\begin{array}{l}\text { Average Seed } \\
\text { Number }\end{array}$ & $\begin{array}{c}\text { Average } \\
500 \text { Seed Weight } \\
{[\mathrm{g}]}\end{array}$ & $\begin{array}{l}\text { Average Seed } \\
\text { Number }\end{array}$ & $\begin{array}{c}\text { Average } \\
500 \text { Seed Weight } \\
{[\mathrm{g}]}\end{array}$ & $\begin{array}{c}\text { Average Seed } \\
\text { Number }\end{array}$ & $\begin{array}{c}\text { Average } \\
500 \text { Seed Weight } \\
{[\mathrm{g}]}\end{array}$ \\
\hline \multicolumn{7}{|c|}{ Male cultivar } \\
\hline Transformation & & & Box-Cox & & & $\log _{10}$ \\
\hline F7 & $133.9 \mathrm{a} \pm 18.2$ & $0.66 c \pm 0.12$ & $166.0 \mathrm{ab} \pm 10.6$ & $0.68 b c \pm 0.06$ & $161.9 \mathrm{ab} \pm 31.6$ & $0.59 b \pm 0.05$ \\
\hline 'Joker' & $111.9 \mathrm{~b} \pm 25.1$ & $0.86 \mathrm{ab} \pm 0.10$ & $142.3 \mathrm{~b} \pm 18.6$ & $0.73 b \pm 0.13$ & $154.8 \mathrm{~b} \pm 42.7$ & $0.65 \mathrm{ab} \pm 0.09$ \\
\hline 'Nostino' & $138.5 \mathrm{a} \pm 14.0$ & $0.88 \mathrm{a} \pm 0.11$ & $165.7 \mathrm{ab} \pm 7.2$ & $0.85 \mathrm{a} \pm 0.11$ & $170.2 \mathrm{ab} \pm 38.1$ & $0.73 \mathrm{a} \pm 0.14$ \\
\hline${ }^{\prime} \operatorname{Rot}^{\prime}$ & $139.5 \mathrm{a} \pm 6.7$ & $0.80 \mathrm{~b} \pm 0.17$ & $167.3 \mathrm{ab} \pm 12.8$ & $0.73 b \pm 0.13$ & $185.1 \mathrm{a} \pm 35.3$ & $0.61 b \pm 0.06$ \\
\hline ‘Rubi' & $138.0 \mathrm{a} \pm 17.7$ & $0.89 a \pm 0.19$ & $173.9 \mathrm{a} \pm 10.6$ & $0.80 \mathrm{ab} \pm 0.13$ & $179.1 \mathrm{a} \pm 27.3$ & $0.61 b \pm 0.06$ \\
\hline 'Tomuri' & $110.0 \mathrm{~b} \pm 26.7$ & $0.65 c \pm 0.08$ & $152.7 \mathrm{ab} \pm 34.2$ & $0.57 \mathrm{c} \pm 0.15$ & $161.1 \mathrm{ab} \pm 17.2$ & $0.26 c \pm 0.06$ \\
\hline ‘Weiki' & $123.4 \mathrm{ab} \pm 28.8$ & $0.84 \mathrm{ab} \pm 0.15$ & $167.2 \mathrm{ab} \pm 18.3$ & $0.77 \mathrm{ab} \pm 0.14$ & $173.3 \mathrm{ab} \pm 26.6$ & $0.62 \mathrm{ab} \pm 0.05$ \\
\hline \multicolumn{7}{|c|}{ Year } \\
\hline 2015 & $144.1 \mathrm{a} \pm 9.2$ & $0.68 b \pm 0.09$ & $168.8 \mathrm{a} \pm 12.4$ & $0.63 b \pm 0.11$ & $195.7 \mathrm{a} \pm 15.5$ & $0.55 \mathrm{a} \pm 0.10$ \\
\hline 2016 & $111.7 b \pm 20.5$ & $0.91 \mathrm{a} \pm 0.12$ & $155.6 \mathrm{~b} \pm 23.2$ & $0.83 a \pm 0.10$ & $143.0 \mathrm{~b} \pm 18.0$ & $0.61 \mathrm{a} \pm 0.19$ \\
\hline
\end{tabular}

Data were analysed using a two-way ANOVA and Tukey's HSD test, with a significance level of $p \leq 0.05$. Values in each column for cultivar and year separately marked with the different letter differ significantly.

The analysis of the Spearman correlation of the fruit examining morphological features showed only weak relationships between some of them. A positive correlation was found between the average fruit weight and average seed number $(0.42 ; p=0.05)$, average 500 seed weight and fruit set $(0.36 ; p=0.05)$ and a negative correlation between the average 500 seed weight and average seed number $(-0.44 ; p=0.05)$.

The performed principal component analysis (PCA) of all components showed the different reactions of female cultivars in each of the research seasons (Figure 4). It can be clearly observed that the 'Weiki' cultivar reacted very similarly to the genetically different pollen in each of the seasons, while the other two female cultivars showed considerable variability. This, however, did not have a significant impact on the examined parameters.

Summing up the above morphological measurements: the best fertilization results, that is, the highest average number of seeds and the highest 500 seeds average weight, was observed for combinations of 'Geneva' $\times$ 'Nostino' or Rubi', 'Weiki' $\times$ 'Nostino', 'Rubi' or 'Weiki' male, and 'Bingo' $\times$ 'Nostino' and 'Weiki' male. It follows that 'Nostino' and 'Rubi' seem to be the best pollinizers for 'Geneva', 'Nostino', 'Rubi' and 'Weiki' male for 'Weiki' female, while 'Nostino' and possibly 'Weiki' for 'Bingo'. The results of the fruit parameters are promising, although those of pollen tube growth highly differed between seasons. The results of the seed parameters confirmed observations of pollen growth through that style where the highest pollination rate was observed for most of the combinations with 'Nostino' and 'Rubi' male cultivars. The fruit weight was rather even. As mentioned above, differences in fruit were noticed between few combinations only in 'Geneva'. We may, therefore, assume that the pollen source has almost no effect on the fruit set and average fruit weight. 

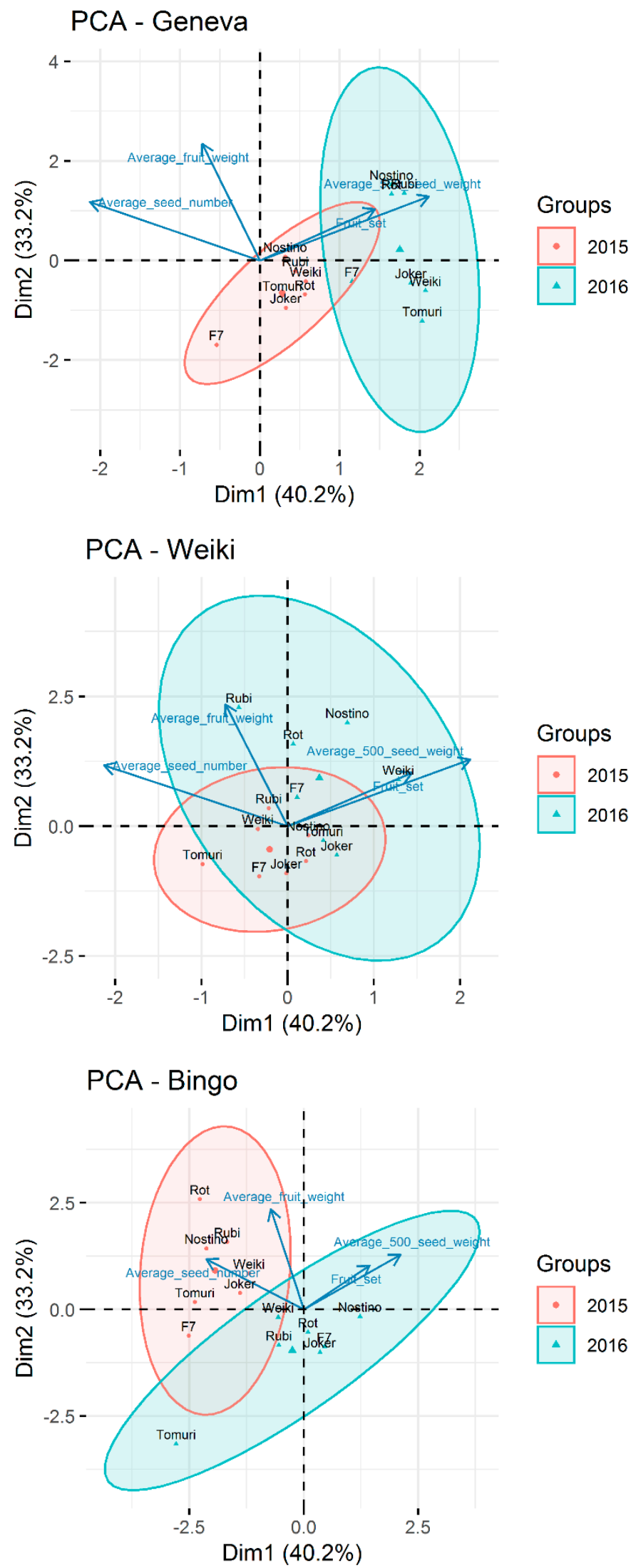

Figure 4. Principal component analysis (PCA) biplot for all model components based on first and second principal components. Plots obtained for the combined data from years 2015 and 2016 and presented for each female cultivar separately. 


\section{Discussion}

Many authors have confirmed that air temperature during pollination may highly influence pollen tube growth and general fertilization, and consequently, fruit set and yield [21,22,24]. In our research, the temperature during flowering, pollination, fruit set and initial fruit grow was rather conducive to pollination, considering that the temperature presented in Figure 1 was average, while it fluctuated on pollination day between 8.6 and $26.7^{\circ} \mathrm{C}$ in 2015 , and between $8.1-19.7^{\circ} \mathrm{C}$ in 2016. Such temperature differences during pollination should not affect the pollen tube growth on stigma, as according to the literature such a range of temperature fluctuations did not influence this process, even for more thermophilic species such as Olea europaea L. [21]. On the other hand, the same authors observed temperature-dependent differences in pollen tube growth through the style resulting in lower fertilization and yield. Such differences were not noticed in this experiment. As shown in Table 3, in both years there were combinations with high rates of pollen germination observed on the stigma, and through the style, to its base. It follows that lower fertilization is rather the result of the pollen source than of the influence of temperature.

Our research showed that pollen of all-male cultivars is characterised by good viability and germination ability. The viability (all results above $80 \%$ ) of imported $A$. chinensis var. deliciosa 'Tomuri' pollen was in the range of data mentioned by other authors $(70.0-97.7 \%)$ [32,33], even notwithstanding long storage. The size of Actinidia pollen grains varied between 24.6 and $29.1 \mu \mathrm{m}$ and similar results were noticed by Jiang et al. [34].

In this experiment, very good stigma covering with pollen grains for most of the combinations was noticed, indicating pollen compatibility and good receptivity of stigmas. It is known that viable and compatible pollen grains adhere to receptive stigma, whereas incompatible or ones which fall on the unreceptive stigma are washed away by rain. Such observations were made by many authors with regard to other fruit species $[29,35,36]$. Combinations, where the number of pollen grains on the stigma rated 3 or 2 on our scale, should be classified as compatible with a high amount of germinating pollen grains. Jerram [37] reports that at least 1870 pollen grains are able to germinate on well-pollinated kiwifruit stigmas. A higher number of pollen tubes growing on the style enhances the chances for fertilizing a higher number of ovules and the formation of well-developed seeds. Erbar [38] describes such relationships for angiosperms. The author claims that high competition between pollen tubes contributes to ovules fertilization with the most valuable genetic material. Hormaza and Herrero [39], as well as Herrero [40], report that competition between pollen tubes and physical and genetic barriers limits and slows down growth to the ovary and the number of pollen tubes in the whole style. A similar relationship was observed in our experiment: many compatible pollen tubes grew throughout the whole length of the style, to the ovary, where fertilization was observed. The amount of pollen grains germinating on stigma and pollen grain size, comparable to common hazel (Corylus avellana L.) or black alder (Alnus glutinosa L.), both typically wind-pollinated plants [41], as well as a great number of pollen grains in inflorescence [12], may suggest that apart from insects, wind plays an important part during the pollination process.

For all analysed female cultivars, compatibility was recorded with most of the seven male genotypes. This was confirmed during fruit analysis as the fruit set was high and equal among each female cultivar. The impact of pollen genotype on the average fruit weight was observed only for 'Geneva' where the differences reached up to $22 \%$. The differences were clearly visible also in seed weight, where the trend of the lowest 500 seed weight for all female A. arguta $\times$ A. chinensis var. deliciosa 'Tomuri' was observed. In 2016, parts of these seeds were not fully developed, but in 2015 were smaller than in other combinations. The inferior seed development could be probably due to the different ploidy levels (hexaploid 'Tomuri' versus tetraploid A. arguta). There are reports that this may impede proper fertilization in actinidia [42]. Differences in the average number of seeds per fruit for all female cultivars were also observed. However, this did not cause differences in fruit weight as was noticed in earlier investigations by Costa et al. [10] and Tiyayon and Strik [15]. 
The fruit set and the average single fruit weight seem to be the most important factors in assessing the yield size. As almost no pollen impact was noticed for these two parameters in our investigation, we assume that successful pollination, that is, delivery of high amounts of pollen, constitutes a crucial factor contributing to high-quality yield. These observations indicate that pollination efforts should be concentrated on the delivery of pollen from the most efficient male $A$. arguta cultivars. These may be grown in the orchard along with female genotypes.

Summarising the above, it follows that cultivars 'Nostino' and 'Rubi' appear to be the most universal pollinizers, and according to Stasiak et al. [12], are also the most efficient pollen donors. Although 'Rot' seems to be a good pollinizer for 'Bingo', its pollen efficiency is significantly lower than that of 'Nostino' and 'Rubi', and so it may not be the best choice for commercial orchards [12]. Pollination using A. chinensis var. deliciosa 'Tomuri' pollen did not increase fruit mass, hence using this source of pollen in a temperate climate (such as prevails in Poland) is not a reasonable option. This corroborates earlier observations of supportive pollination using 'Tomuri' pollen on A. arguta 'Weiki' and 'Geneva' [14]. Moreover, $A$. chinensis pollen may serve as a vector of bacterial cancer (Psa), a dangerous quarantine disease caused by Pseudomonas syringae pv. actinidiae [42,43].

\section{Conclusions}

An average temperature between $15{ }^{\circ} \mathrm{C}$ and $18{ }^{\circ} \mathrm{C}$ during flowering and pollination seems to be satisfactory enough for $A$. arguta pollination and fertilization. Stigmas of $A$. arguta 'Geneva', 'Weiki' and 'Bingo' flowers proved to be highly receptive and compatible with pollen of most tested male cultivars. However, some significant differences between the efficiency of diverse pollen donors were observed. This indicates that the best pollinizer for a specific female cultivar in commercial fruit production should be sought. 'Nostino' and 'Rubi' appeared to be the most suitable pollinizers for the three tested female A. arguta cultivars. Artificial pollination using commercially available A. chinensis var. deliciosa 'Tomuri' pollen proved to be ineffective and therefore inappropriate for use in Polish conditions. The high amount of pollen grains germinating on stigma and small pollen grain size suggests that apart from insects, an important part during the pollination process in Actinidia is also played by the wind.

Author Contributions: Conceptualization, methodology, validation, A.S. and P.L.; performed the experiments, formal analysis, visualisation, A.S.; writing —original draft preparation, A.S. and P.L.; analysis of pollen tube growth in vivo, visualisation, M.B.; supervision, P.L.; writing-review and editing, A.S. and P.L. All authors have read and agreed to the published version of the manuscript.

Funding: This research was partly supported by the National Centre for Research and Development (NCBR), Poland, grant number PBS3/A8/35/2015.

Institutional Review Board Statement: Not applicable.

Informed Consent Statement: Not applicable.

Data Availability Statement: The data presented in this study are available on request from the corresponding author.

Conflicts of Interest: The authors declare no conflict of interest.

\section{References}

1. Käfer, J.; Marais, G.A.B.; Pannell, J.R. On the rarity of dioecy in flowering plants. Mol. Ecol. 2017, 26, 1225-1241. [CrossRef]

2. de Jong, T.J.; Batenburg, J.C.; Klinkhamer, P.G.L. Distance-dependent pollen limitation of seed set in some insect-pollinated dioecious plants. Acta Oecol. 2005, 28, 331-335. [CrossRef]

3. Gaaliche, B.; Trad, M.; Mars, M. Effect of pollination intensity, frequency and pollen source on fig (Ficus carica L.) productivity and fruit quality. Sci. Hortic. 2011, 130, 737-742. [CrossRef]

4. Ferguson, A.R. Botanical Description. In The Kiwifruit Genome; Testolin, R., Huang, H.-W., Ferguson, R., Eds.; Springer Science and Business Media LLC: New York, NY, USA, 2016; pp. 1-13. [CrossRef]

5. Lim, T.K. Actinidia arguta. In Edible Medicinal and Non-Medicinal Plants: Vol. 1, Fruits; Springer, Science and Business Media B.V.: New York, NY, USA, 2012; pp. 5-11. [CrossRef] 
6. Leontowicz, H.; Leontowicz, M.; Latocha, P.; Jesion, I.; Park, Y.-S.; Katriche, E.; Barasche, D.; Nemirovski, A.; Gorinstein, S. Bioactivity and nutritional properties of hardy kiwi fruit Actinidia arguta in comparison with Actinidia deliciosa 'Hayward' and Actinidia eriantha 'Bidan'. Food Chem. 2016, 196, 281-291. [CrossRef]

7. Leontowicz, M.; Leontowicz, H.; Jesion, I.; Bielecki, W.; Najman, K.; Latocha, P.; Park, Y.-S.; Gorinstein, S. Actinidia arguta supplementation protects aorta and liver in rats with induced hypercholesterolemia. Nutr. Res. 2016, 36, 1231-1242. [CrossRef]

8. Latocha, P.; Łata, B.; Stasiak, A. Phenolics, ascorbate and the antioxidant potential of kiwiberry vs. common kiwifruit: The effect of cultivar and tissue type. J. Funct. Foods 2015, 19, 155-163. [CrossRef]

9. Latocha, P. The nutritional and health benefits of kiwiberry (Actinidia arguta)—A review. Plant. Foods Hum. Nutr. 2017, 72, 325-334. [CrossRef]

10. Costa, G.; Testolin, R.; Vizzotto, G. Kiwifruit pollination: An unbiased estimate of wind and bee contribution. N. Z. J. Crop. Hort. 1993, 21, 189-195. [CrossRef]

11. Fraser, L.; Mcneilage, M. Reproductive Biology. In The Kiwifruit Genome; Testolin, R., Huang, H.-W., Ferguson, R., Eds.; Springer Science and Business Media LLC: New York, NY, USA, 2016; pp. 65-84. [CrossRef]

12. Stasiak, A.; Łata, B.; Bieniasz, M.; Latocha, P. Morphological variation of male A. arguta plants affects their flowering potential and pollen efficiency. Hort. Sci. 2020, 47, 100-109. [CrossRef]

13. Sáez, A.; Negri, Z.P.; Viel, M.; Aizen, M.A. Pollination efficiency of artificial and bee pollination practices in kiwifruit. Sci. Hortic. 2019, 246, 1017-1021. [CrossRef]

14. Stasiak, A.; Stefaniak, J.; Łata, B.; Latocha, P. Efficiency of A. arguta (Siebold et Zucc.) Planch, Ex. Miq. pollination using A. deliciosa pollen. J. Int. Sci. Publ. Agric. Food 2017, 5, 178-187. Available online: https://www.scientific-publications.net/en/ article/1001407/ (accessed on 18 June 2021).

15. Tiyayon, C.; Strik, B. Flowering and fruiting morphology of hardy kiwifruit A. arguta. Acta Hortic. 2003, 610, 171-176. [CrossRef]

16. Gonzales, M.V.; Coque, M.; Herrero, M. Kiwifruit flower biology and its implications on fruit set. Acta Hortic. 1997, 444, 425-429. [CrossRef]

17. Mohammadi, N.; Rastgoo, S.; Izadi, M. The strong effect of pollen source and pollination time on fruit set and the yield of tissue culture-derived date palm (Phoenix dactylifera L.) trees cv. Barhee. Sci. Hortic. 2017, 224, 343-350. [CrossRef]

18. Seal, A.G.; Dunn, J.K.; De Silva, H.N.; McGhie, T.K.; Lunken, R.C.M. Choice of pollen parent affects red flesh colour in seedlings of diploid Actinidia chinensis (kiwifruit). N. Z. J. Crop. Hort. 2013, 41, 207-218. [CrossRef]

19. Stasiak, A.; Latocha, P.; Drzewiecki, J.; Hallman, E.; Najman, K.; Leontowicz, H.; Leontowicz, M.; Łata, B. The choice of female or male parent affects some biochemical characteristics of fruit or seed of kiwiberry (Actinidia arguta). Euphytica 2019, 215, 52. [CrossRef]

20. Pourghayoumi, M.; Bakhshia, D.; Rahemib, M.; Jafari, M. Effect of pollen source on quantitative and qualitative characteristics of dried figs (Ficus carica L.) cvs 'Payves' and 'Sabz' in Kazerun-Iran. Sci. Hortic. 2012, 147, 98-104. [CrossRef]

21. Selak, G.V.; Perica, S.; Ban, S.G.; Poljak, M. The effect of temperature and genotype on pollen performance in olive (Olea europaea L.). Sci. Hortic. 2013, 156, 38-46. [CrossRef]

22. Polito, V.S.; Weinbaum, S.A. Intraclonal Variation in Pollen Germinability in Kiwifruit, Pistachio and Walnut as Influenced by Tree Age. Sci. Hortic. 1988, 36, 97-102. [CrossRef]

23. Shivanna, K.R.; Heslop-Harrison, Y.; Heslop-Harrison, J. The pollen-stigma interaction in the grasses. 3. Features of the self-incompatibility response. Acta Bot. Neerl. 1982, 31, 307-319. [CrossRef]

24. Hebbar, K.B.; Rose, H.M.; Nair, A.R.; Kannana, S.; Niral, V.; Arivalagan, M.; Gupta, A.; Samsudeen, K.; Chandran, K.P.; Chowdappa, P.; et al. Differences in in vitro pollen germination and pollen tube growth of coconut (Cocos nucifera L.) cultivars in response to high temperature stress. Environ. Exp. Bot. 2018, 153, 35-44. [CrossRef]

25. Alvarez, H.C.; Salazar-Gutiérrez, M.; Chaves, B. Modelling pollen tube growth of 'Gala' and 'Fuji' apples. Sci. Hortic. 2018, 240, 125-132. [CrossRef]

26. Padureanu, S.; Patras, A. Germination potential and pollen tube growth in Galanthus nivalis L. Flora 2020, 264, 151556. [CrossRef]

27. Strik, B.; Growing Kiwifruit. PNW 507 Oregon State Univ. Extension Service 2005. Available online: https://catalog.extension. oregonstate.edu/pnw507 (accessed on 20 March 2018).

28. Alexander, M.P. Differential staining of aborted and nonaborted pollen. Stain Technol. 1969, 44, 117-122. [CrossRef]

29. Bieniasz, M.; Dziedzic, E.; Słowik, G. Biological features of flowers influencing the fertility of Lonicera spp. cultivars. Hortic. Environ. Biotechnol. 2019, 60, 155-166. [CrossRef]

30. Radice, S.; Arena, M.E. Reproductive shoots of Berberis microphylla G. Forst.in relation with the floral bud development and the fruit set. Heliyon 2018, 4, e00927. [CrossRef]

31. Tarantino, A.; Lops, F.; Disciglio, G.; Lopriore, G. Effects of plant biostimulants on fruit set, growth, yield and fruit quality attributes of 'Orange rubis ${ }^{\circledR \prime}$ apricot (Prunus armeniaca L.) cultivar in two consecutive years. Sci. Hortic. 2018, 239, 26-34. [CrossRef]

32. Abreu, I.; Oliveira, M. Fruit production in kiwifruit (Actinidia deliciosa) using preserved pollen. Aust. J. Agr. Res. 2004, 55, 565-569. [CrossRef]

33. Borghezan, M.; Clauman, A.D.; Steinmacher, D.A.; Guerra, M.P.; Orth, A.I. In vitro viability and preservation of pollen kiwi (Actinidia chinensis var. deliciosa (A. Chev) A. Chev). Crop Breed. Appl. Biot. 2011, 11, 338-344. 
34. Jiang, Z.-W.; Wang, S.-M.; Zhang, Z.-H.; Huang, H.-W. Pollen morphology of Actinidia and its systematic significance. J. Syst. Evol. 2004, 42, 245-260. Available online: https:/ / www.jse.ac.cn/EN/Y2004/V42/I3/245 (accessed on 18 June 2021).

35. Sękara, A.; Bieniasz, M. Pollination, fertilization and fruit formation in eggplant (Solanum melongena L.). Acta Agrobot. 2008, 61, 107-113. [CrossRef]

36. Bieniasz, M.; Necas, T.; Dziedzic, E.; Ondrasek, I.; Pawłowska, B. Evaluation of pollen quality and self-fertility in selected cultivars of Asian and European pears. Not. Bot. Horti. Agrobo. 2017, 45, 375-382. [CrossRef]

37. Jerram, M. Pollination of kiwifruit (Actinidia chinensis Planch.): Stigma-style structure and pollen tube growth. N. Z. J. Bot. 1979, 17, 233-240. [CrossRef]

38. Erbar, C. Pollen tube transmitting tissue: Place of competition of male gametophytes. J. Plant. Sci. 2003, 164 (Suppl. 5), S265-S277. [CrossRef]

39. Hormaza, J.I.; Herrero, M. Dynamics of pollen tube growth under different competition regimes. Sex. Plant. Reprod. 1996, 9, 153-160. [CrossRef]

40. Herrero, M. Changes in the ovary related to pollen tube guidance. Ann. Bot.-Lond. 2000, 85 (Suppl. A), 79-85. [CrossRef]

41. Piotrowska, K. Ecological features of flowers and the amount of pollen released in Corylus avellana (L.) and Alnus glutinosa (L.) Gaertn. Acta. Agrobot. 2008, 61, 33-39. [CrossRef]

42. Ferguson, A.R.; Huang, H. Cytology, Ploidy and Ploidy Manipulation. In The Kiwifruit Genome; Testolin, R., Huang, H.-W., Ferguson, R., Eds.; Springer Science and Business Media LLC: New York, NY, USA, 2016. [CrossRef]

43. Tontou, R.; Giovanardi, D.; Stefani, E. Pollen as a possible pathway for the dissemination of Pseudomonas syringe pv. actinidiae and bacterial canker of kiwifruit. Phytopathol. Mediterr. 2014, 53, 333-339. [CrossRef] 